\title{
Heterosis for Grain Yield and Yield Components in Bread Wheat (Triticum aestivum L.) Over Environments
}

\author{
Ramesh Kumar*, D.R. Mehta, V. S. Shekhawat, S. Patel Nikita and N. Vora Zarna \\ Department of Genetics and Plant Breeding, College of Agriculture, Junagadh Agricultural \\ University, Junagadh, Gujarat, India \\ *Corresponding author
}

\section{A B S T R A C T}

\section{Keywords}

Bread wheat,

Heterobeltiosis,

Standard heterosis,

Grain yield

Article Info

Accepted:

26 June 2019

Available Online:

10 July 2019
Ten parents along with forty-five hybrids (developed by half-diallel) and one check (Lok 1) were evaluated in randomized block design with three replications in three environments [early sowing $\left(E_{1}\right)$, normal sowing $\left(E_{2}\right)$ and late sowing $\left(\mathrm{E}_{3}\right)$ ] during rabi 2016-17. The significant and positive heterobeltiosis was recorded for grain yield per plant by seven crosses in $E_{1}$; nine crosses in $E_{2}$; and six crosses in $E_{3}$, while 31 crosses in $E_{1} ; 19$ crosses in $E_{2}$; and 38 crosses in $E_{3}$ exhibited significant and positive standard heterosis. In general, magnitude of heterosis over better parent and standard check for grain yield per plant was medium and high, respectively. Comparison of crosses on the basis of per se performance, heterosis over better parent and standard check for grain yield per plant revealed that five crosses viz., GW 463 x DBW 110, GW 455 x MP 3288, GW 455 x MP 3288, GW 273 x Raj 4238 and GW 451 x HD 2932 manifested significant and desirable heterobeltiosis and standard heterosis in all the three environments (except GW 455 x MP 3288 for heterobeltiosis in $\mathrm{E}_{3}$ ).

\section{Introduction}

Wheat (Tritium aestivum L.) is the second most important crop that contributes significantly to the global food and food security (Thomas et al., 2017). It provides food to 36 per cent of the global population contributing 20 per cent of total food calories for the world people and is a national staple in many countries. The total production of wheat in the world is around 749.46 million tonnes covering an area of about 220.10 million ha with an average productivity of $3405.0 \mathrm{~kg} \mathrm{ha}^{-1}$ (Anon., 2016). The area and production of wheat in India during year 2016-17 was recorded 30.72 million ha and 97.44 million tonnes with an average productivity of 3172 $\mathrm{kg} \mathrm{ha}^{-1}$ (Anon., 2017). Best vegetative and reproduction growth of wheat plant is obtained at temperature $18-22{ }^{\circ} \mathrm{C}$ (Hennessy et al., 
2008 and Reynolds et al., 2010). In selfpollinated crop like wheat, where commercial hybrid seed production is not feasible due to lack of suitable mechanism to produce hybrid seed, exploitation of hybrid vigour is limited.

Therefore, at present heterosis per se may not be of economic value in this crop. Heterosis in wheat is used to select desirable crosses to obtain superior transgressive segregants in advance generations for additional enrichment of grain yield. In present study per cent increase or decrease over better parent (heterobeltiosis) and standard check, Lok 1 (standard heterosis) was used as a measure of heterosis.

\section{Materials and Methods}

The experiment was conducted at Wheat Research Station, J.A.U., Junagadh during rabi 2016-17. Ten parents (GW 451, GW 463, GW 455, GW 273, GW 477, DBW 110, HD 2932, Raj 4238, MP 3288 and UP 2672) along with forty-five hybrids (developed by diallel excluding reciprocals) and one check (Lok 1) were evaluated in randomized block design with three replications in three environments [early sowing $\left(\mathrm{E}_{1}\right)$, normal sowing $\left(\mathrm{E}_{2}\right)$ and late sowing $\left.\left(\mathrm{E}_{3}\right)\right]$.

The planting material was received from breeding unit Wheat Research Station, Junagadh Agricultural University, Junagadh, Gujarat. Five competitive plants from each plot were randomly selected in all the three environments for recording observations on various characters. However, days to heading and days to maturity were recorded on plot basis. Observations were recorded for fifteen traits viz., days to 50 per cent heading, plant height, number of effective tillers, length of spike, peduncle length of main spike, days to maturity, number of grains per spike, grain weight per spike, 1000-grain weight, grain yield per plant, biological yield per plant, harvest index, canopy temperature, flag leaf area and chlorophyll content.

Estimation of heterobeltiosis and standard heterosis by Fonseca and Patterson (1968) and Briggle (1963), respectively were calculated for each character using the following formula

Heterosis over better parent (heterobeltiosis) $=\frac{\mathrm{F} 1-\mathrm{BP}}{\mathrm{BP}} \times 100$

Heterosis over check (standard heterosis) $=\frac{\mathrm{F} 1-\mathrm{CC}}{\mathrm{CC}} \times 100$

Where,

$F_{1}=$ mean performance of $F_{1}$

$\mathrm{BP}=$ mean performance of better parent

$\mathrm{CC}=$ mean performance of the best commercial check.

\section{Results and Discussion}

In present investigation, the range of heterosis has been estimated for all the characters. Wide range of heterosis usually indicates the amount of variability for the heterosis. An overall appraisal of the Table 1 revealed range of heterosis over better parent for days to 50 per cent heading from -28.16 to 18.56 in $E_{1},-29.65$ to 23.03in $\mathrm{E}_{2}$ and-18.35 to 21.58in $\mathrm{E}_{3}$; for plant height from -32.86 to 26.71in $\mathrm{E}_{1},-30.05$ to 18.91in $\mathrm{E}_{2}$ and -54.95 to 8.86in $\mathrm{E}_{3}$;for number of effective tillers from -36.52 to 52.05 in $\mathrm{E}_{1}$,39.32 to 44.69 in $\mathrm{E}_{2}$ and -42.84 to 21.93in $\mathrm{E}_{3}$; for length of spike from -29.74 to 44.73in $E_{1},-27.44$ to 44.16 in $E_{2}$ and -25.29 to 37.99in $\mathrm{E}_{3}$; for peduncle length of main spike from 36.76 to 52.25 in $\mathrm{E}_{1},-13.50$ to 44.20 in $\mathrm{E}_{2}$ and 45.59 to $10.86 \mathrm{in} \mathrm{E}_{3}$; for days to maturity from 13.27 to 10.88 in $\mathrm{E}_{1},-13.56$ to 23.92 in $\mathrm{E}_{2}$ and 11.96 to 23.85 in $\mathrm{E}_{3}$; for number of grains per spike from -23.20 to 48.34 in $\mathrm{E}_{1},-18.83$ to 
46.04in $\mathrm{E}_{2}$ and -44.61 to 56.96 in $\mathrm{E}_{3}$;for grain weight per spike from -45.58 to 78.00 in $\mathrm{E}_{1}$, 30.04 to $136.04 \mathrm{in} \mathrm{E}_{2}$ and -56.76 to $57.26 \mathrm{in}$ $\mathrm{E}_{3}$; for 1000-grain weight from -44.13 to 13.94 in $E_{1},-29.49$ to 31.09 in $E_{2}$ and -46.29 to 39.31 in $E_{3}$; for grain yield per plant from 59.20 to 3.22 in $\mathrm{E}_{1},-57.31$ to 28.27 in $\mathrm{E}_{2}$ and 59.16 to 29.39 in $\mathrm{E}_{3}$; for biological yield per plant from -52.28 to 42.07 in $\mathrm{E}_{1},-39.19$ to 42.70 in $E_{2}$ and -56.80 to 1.07 in $E_{3}$; for harvest index from -52.39 to 19.61 in $\mathrm{E}_{1}$, 43.41 to 30.47 in $\mathrm{E}_{2}$ and -40.03 to 47.89 in $\mathrm{E}_{3}$; for canopy temperature from -11.71 to 27.11 in $E_{1},-14.79$ to 19.42 in $E_{2}$ and-8.69 to 20.40 in $\mathrm{E}_{3}$; for flag leaf area from -30.61 to 16.01 in $E_{1},-20.53$ to 27.02 in $E_{2}$ and -29.05 to 37.24 in $E_{3}$; for chlorophyll content from -42.69 to 25.39 in $\mathrm{E}_{1},-27.35$ to 37.38 in $\mathrm{E}_{2}$ and -38.80 to 30.24 in $E_{3}$. In general magnitude of heterobeltiosis (\%) was high in $\mathrm{E}_{2}$ among all the three environments (Fig. 1), while heterosis over standard check (Lok 1) was found high in $\mathrm{E}_{3}$ (Fig. 2).

While considering the performance of crosses in individual environment with respect to grain yield per plant, seven crosses in $\mathrm{E}_{1}$, nine crosses in $E_{2}$ and six crosses in $E_{3}$ over better parent, while 31 crosses in $\mathrm{E}_{1}, 19$ crosses in $\mathrm{E}_{2}$ and 38 crosses in $\mathrm{E}_{3}$ over standard check exhibited significant and positive heterosis. The range of heterosis over standard check for grain yield per plant in per cent was from 47.18 to 66.69 in $\mathrm{E}_{1} ;-48.46$ to $52.84 \mathrm{in} \mathrm{E}_{2}$; and 35.27 to 98.14in $\mathrm{E}_{3}$. Seventeen crosses viz., GW 451 x HD 2932, GW 451 x UP 2672, GW 463 x DBW 110, GW 463 x HD 2932, GW 463 x Raj 4238, GW 455 x GW 273, GW 455 x GW 477, GW 455 x MP 3288, GW 273 x Raj 4238, GW 273 x MP 3288, GW 477 x HD 2932, GW 477 x Raj 4238, GW 477 x UP 2672, DBW 110 x HD 2932, HD 2932 x Raj 4238, HD 2932 x MP 3288 and MP 3288 x UP 2672 exhibited significant and positive economic heterosis in all the environments. High heterosis for grain yield has recently been reported by Barot et al., (2014); Thomas et al., (2017) and Aware and Potdukhe (2018). It is of profound interest to know the cause of heterosis for grain yield. Whitehouse et al., (1958) and Grafius (1959) suggested that there may not be any gene system for grain yield per se, as grain yield is an end product of the multiplicative interaction among the yield components. This would indicate that the heterosis for grain yield should be through heterosis for the individual yield components or alternatively due to the multiplicative effect of partial dominance of component characters. Williams and Gilbert (1960) reported that even simple dominance in respect of yield components may lead to expression of heterosis for yield. Hagberg (1952) observed similar effects and termed it "combinational heterosis". In order to see whether similar situation exist in bread wheat or not, a comparison of six most heterotic crosses for grain yield was made with other yield related characters along with average grain yield per plant in all the three environments (Table 2 to Table 4). Six crosses viz., GW 463 x DBW 110, GW 455 x MP 3288, HD 2932 x Raj 4238, GW 273 x Raj 4238, GW 451 x HD 2932 and GW 463 x HD 2932 manifested significant and desirable heterobeltiosis for grain yield per plant also recorded significant and positive heterobeltiosis for 1000-grain weight (6 cases) followed by number of effective tillers per plant, grain weight per spike and biological yield per plant (5 cases in each) in $\mathrm{E}_{1}$ (Table 2).

On the other hand, six crosses viz., GW $463 \mathrm{x}$ DBW 110, GW 273 x Raj 4238, GW 451 x HD 2932, HD 2932 x Raj 4238, GW 455 x MP 3288 and GW 455 x GW 273manifested significant and desirable heterobeltiosis for grain yield per plant (except GW 455 x GW 273) also recorded significant and positive heterobeltiosis for various yield contributing characters on individual cross basis in $\mathrm{E}_{2}$. For example, 1000-grain weight (5 cases) 
followed by number of effective tillers per plant, grain weight per spike, biological yield per plant, canopy temperature and chlorophyll content (3 case in each) in $\mathrm{E}_{2}$ (Table 3). Similarly, six crosses viz., GW 463 x DBW 110, GW 273 x Raj 4238, GW 455 x MP 3288, GW 451 x HD 2932, HD 2932 x Raj 4238 and GW 463 x HD 2932manifested significant and desirable heterobeltiosis for grain yield per plant also recorded significant and positive heterobeltiosis for peduncle length of main spike and harvest index (6 cases each) followed by 1000-grain weight, number of grains per spike ( 5 cases each) and chlorophyll content (4 cases) in $\mathrm{E}_{3}$ (Table 4). Out of these six crosses, five crosses viz., GW 463 x DBW 110, GW 273 x Raj 4238, GW 455 x MP 3288, GW $451 \times$ HD 2932 and HD 2932 x Raj 4238 were founded common in all the three environments.

Fig.1 Radar showing trend of heterobeltiosis (\%) of 45 crosses over the environments

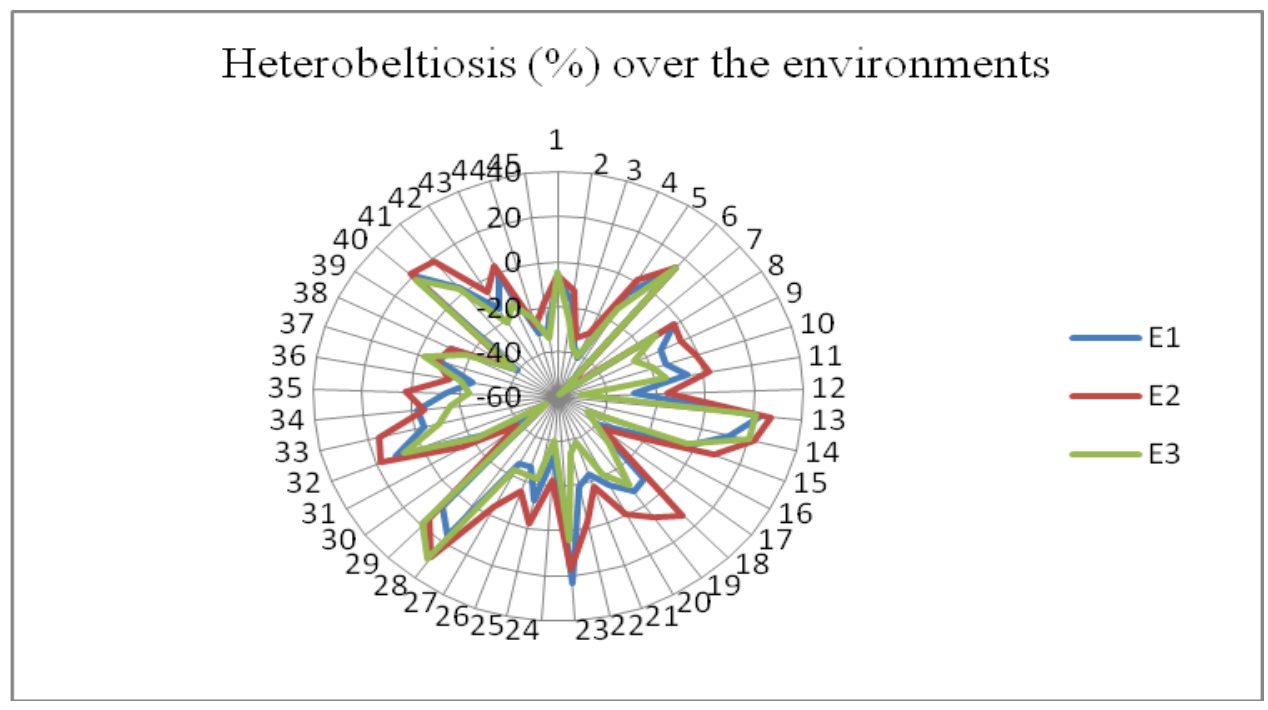

Fig.2 Radar showing trend of standard heterosis (\%) of 45 crosses over the environments

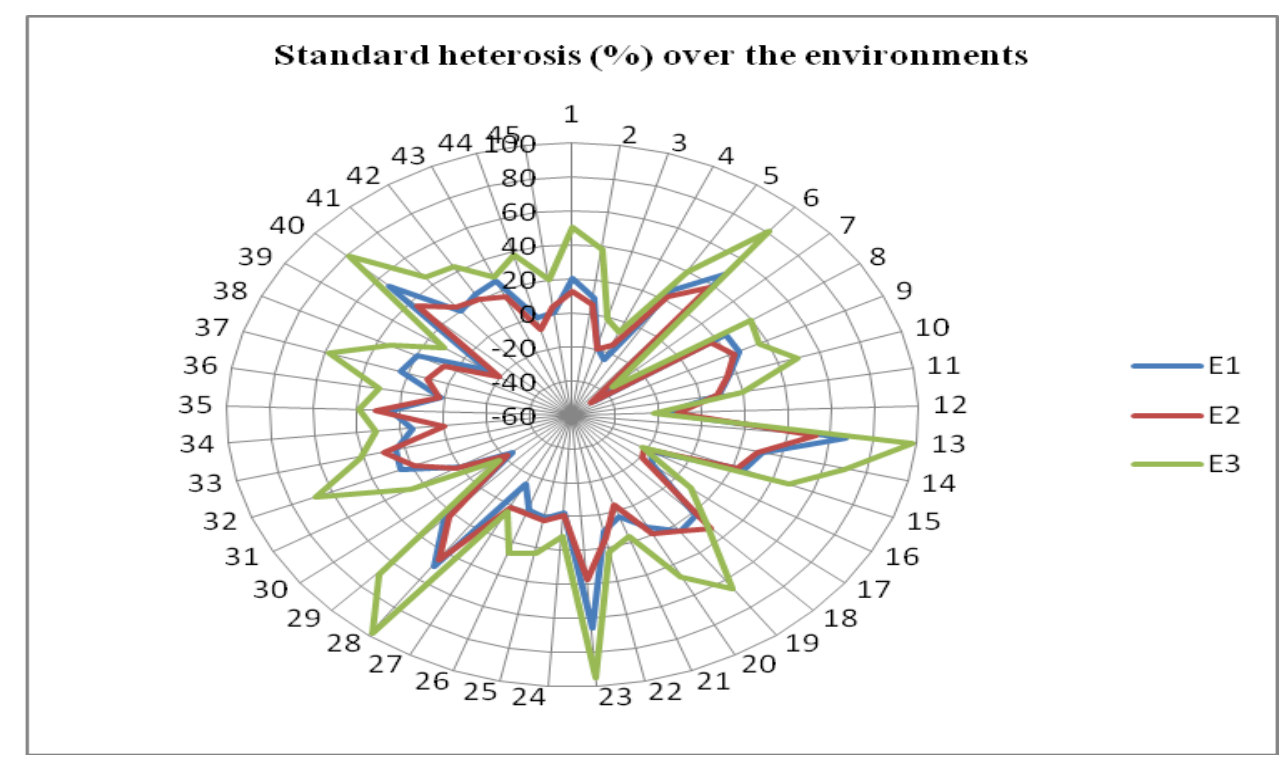


Table.1 Magnitude of heterobeltiosis and standard heterosis for various characters in bread wheat

\begin{tabular}{|c|c|c|c|c|c|c|c|c|c|}
\hline \multirow{3}{*}{ S.N. } & \multirow{3}{*}{ Crosses } & \multirow[t]{3}{*}{ Env } & \multirow{3}{*}{$\begin{array}{c}\text { Desirable } \\
\text { aspect }\end{array}$} & \multicolumn{2}{|c|}{ Range } & \multicolumn{4}{|c|}{$\begin{array}{l}\text { Number of crosses with } \\
\text { significant heterosis }\end{array}$} \\
\hline & & & & \multirow[t]{2}{*}{$\mathbf{H}(\%)$} & \multirow[t]{2}{*}{ SH (\%) } & \multicolumn{2}{|c|}{$\mathbf{H}(\%)$} & \multicolumn{2}{|c|}{ SH (\%) } \\
\hline & & & & & & $+\mathbf{v e}$ & -ve & +ve & -ve \\
\hline \multirow[t]{3}{*}{1.} & \multirow[t]{3}{*}{ Day to $50 \%$ heading } & $\mathrm{E}_{1}$ & \multirow[t]{3}{*}{ Early } & -28.16 to 18.56 & -14.38 to 40.41 & 6 & 8 & 38 & 6 \\
\hline & & $\mathrm{E}_{2}$ & & -29.65 to 23.03 & -15.38 to 32.17 & - & 10 & 30 & 9 \\
\hline & & $\mathrm{E}_{3}$ & & -18.35 to 21.58 & -16.11 to 13.42 & 5 & 10 & 2 & 13 \\
\hline \multirow[t]{3}{*}{2.} & \multirow[t]{3}{*}{ Plant height $(\mathrm{cm})$} & $\mathrm{E}_{1}$ & \multirow[t]{3}{*}{ Dwarf } & -32.86 to 26.71 & -10.55 to 40.37 & - & 14 & 25 & 10 \\
\hline & & $\mathrm{E}_{2}$ & & -30.05 to 18.91 & -16.19 to 23.02 & 1 & 14 & 6 & 12 \\
\hline & & $\mathrm{E}_{3}$ & & -54.95 to 8.86 & -43.68 to 14.82 & 2 & 31 & 14 & 19 \\
\hline \multirow[t]{3}{*}{3.} & \multirow[t]{3}{*}{ No. of effective tillers } & $\mathrm{E}_{1}$ & \multirow[t]{3}{*}{ High } & -36.52 to 52.05 & -22.41 to 72.36 & 18 & 7 & 29 & 6 \\
\hline & & $\mathrm{E}_{2}$ & & -39.32 to 44.69 & -40.42 to 45.32 & 19 & 2 & 18 & 3 \\
\hline & & $\mathrm{E}_{3}$ & & -42.84 to 21.93 & -31.33 to 22.64 & 1 & 15 & 3 & 13 \\
\hline \multirow[t]{3}{*}{4.} & \multirow[t]{3}{*}{ Length of spike $(\mathrm{cm})$} & $\mathrm{E}_{1}$ & \multirow[t]{3}{*}{ High } & -29.74 to 44.73 & 2.38 to 70.00 & 18 & 16 & 45 & - \\
\hline & & $\mathrm{E}_{2}$ & & -27.44 to 44.16 & -3.25 to 60.57 & 19 & 15 & 42 & 1 \\
\hline & & $\mathrm{E}_{3}$ & & -25.29 to 37.99 & 0.00 to 72.31 & 24 & 13 & 43 & - \\
\hline \multirow[t]{3}{*}{5.} & \multirow{3}{*}{$\begin{array}{l}\text { Peduncle length of main } \\
\text { spike }\end{array}$} & $\mathrm{E}_{1}$ & \multirow[t]{3}{*}{ Short } & -36.76 to 52.25 & -12.99 to 40.97 & 11 & 5 & 36 & 7 \\
\hline & & $\mathrm{E}_{2}$ & & -13.50 to 44.20 & -14.36 to 22.00 & 8 & 5 & 14 & 8 \\
\hline & & $\mathrm{E}_{3}$ & & -45.59 to 10.86 & -41.47 to -1.44 & 6 & 37 & - & 43 \\
\hline \multirow[t]{3}{*}{6.} & \multirow[t]{3}{*}{ Days to maturity } & $\mathrm{E}_{1}$ & \multirow[t]{3}{*}{ Early } & -13.27 to 10.88 & -5.39 to 14.81 & - & 10 & - & 10 \\
\hline & & $\mathrm{E}_{2}$ & & -13.56 to 23.92 & -15.95 to 4.98 & 2 & 9 & - & 11 \\
\hline & & $\mathrm{E}_{3}$ & & -11.96 to 23.85 & -11.81 to 9.23 & 1 & 3 & - & 4 \\
\hline \multirow[t]{3}{*}{7.} & \multirow[t]{3}{*}{ Number of grains per spike } & $\mathrm{E}_{1}$ & \multirow[t]{3}{*}{ High } & -23.20 to 48.34 & 11.90 to 63.07 & 6 & 2 & 42 & - \\
\hline & & $\mathrm{E}_{2}$ & & -18.83 to 46.04 & -1.92 to 28.22 & 8 & 1 & 14 & 1 \\
\hline & & $\mathrm{E}_{3}$ & & -44.61 to 56.96 & -33.07 to 27.13 & 2 & 25 & 10 & 17 \\
\hline 8. & Grain weight per spike & $\mathrm{E}_{1}$ & High & -45.58 to 78.00 & -35.35 to 16.76 & 5 & 18 & 6 & 26 \\
\hline & & $\mathrm{E}_{2}$ & & -30.04 to 136.04 & -21.09 to 29.23 & 14 & 7 & 18 & 6 \\
\hline & & $\mathrm{E}_{3}$ & & -56.76 to 57.26 & -39.96 to 51.95 & 3 & 16 & 3 & 15 \\
\hline
\end{tabular}


Table.1 Contd....

\begin{tabular}{|c|c|c|c|c|c|c|c|c|c|}
\hline \multirow{3}{*}{$\begin{array}{l}\text { S. } \\
\text { N. }\end{array}$} & \multirow{3}{*}{ Crosses } & \multirow[t]{3}{*}{ Env } & \multirow{3}{*}{$\begin{array}{l}\text { Desirable } \\
\text { aspect }\end{array}$} & \multicolumn{2}{|c|}{ Range } & \multicolumn{4}{|c|}{$\begin{array}{l}\text { Number of crosses with } \\
\text { significant heterosis }\end{array}$} \\
\hline & & & & \multirow[t]{2}{*}{$\mathbf{H}(\%)$} & \multirow[t]{2}{*}{ SH (\%) } & \multicolumn{2}{|c|}{ H $(\%)$} & \multicolumn{2}{|c|}{ SH (\%) } \\
\hline & & & & & & +ve & -ve & $+v e$ & -ve \\
\hline \multirow[t]{3}{*}{9.} & \multirow[t]{3}{*}{ 1000-Grain weight } & $\mathrm{E}_{1}$ & \multirow[t]{3}{*}{ High } & -44.13 to 13.94 & -37.04 to 16.78 & 2 & 38 & 1 & 44 \\
\hline & & $\mathrm{E}_{2}$ & & -29.49 to 31.09 & -21.36 to 21.32 & 8 & 31 & 8 & 36 \\
\hline & & $\mathrm{E}_{3}$ & & -46.29 to 39.31 & -39.82 to 17.69 & 5 & 33 & 2 & 42 \\
\hline \multirow[t]{3}{*}{10.} & \multirow[t]{3}{*}{ Grain yield per plant } & $\mathrm{E}_{1}$ & \multirow[t]{3}{*}{ High } & -59.20 to 3.22 & -47.18 to 66.69 & 7 & 26 & 31 & 12 \\
\hline & & $\mathrm{E}_{2}$ & & -57.31 to 28.27 & -48.46 to 52.84 & 9 & 16 & 19 & 12 \\
\hline & & $\mathrm{E}_{3}$ & & -59.16 to 29.39 & -35.27 to 98.14 & 6 & 32 & 38 & 6 \\
\hline \multirow[t]{3}{*}{11.} & \multirow[t]{3}{*}{ Biological yield per plant } & $\mathrm{E}_{1}$ & \multirow[t]{3}{*}{ High } & -52.28 to 42.07 & -31.19 to 62.05 & 9 & 20 & 43 & 2 \\
\hline & & $\mathrm{E}_{2}$ & & -39.19 to 42.70 & -26.63 to 44.34 & 3 & 17 & 28 & 3 \\
\hline & & $\mathrm{E}_{3}$ & & -56.80 to 1.07 & -13.47 to 86.17 & - & 33 & 43 & 1 \\
\hline \multirow[t]{3}{*}{12.} & \multirow[t]{3}{*}{ Harvest index } & $\mathrm{E}_{1}$ & \multirow[t]{3}{*}{ High } & -52.39 to 19.61 & -48.04 to 16.35 & 6 & 32 & 8 & 31 \\
\hline & & $\mathrm{E}_{2}$ & & -43.41 to 30.47 & -38.66 to 17.29 & 5 & 14 & 5 & 14 \\
\hline & & $\mathrm{E}_{3}$ & & -40.03 to 47.89 & -41.86 to 18.99 & 11 & 10 & 9 & 14 \\
\hline \multirow[t]{3}{*}{13.} & \multirow[t]{3}{*}{ Canopy temperature } & $\mathrm{E}_{1}$ & \multirow[t]{3}{*}{ Low } & -11.71 to 27.11 & -5.48 to 24.60 & 5 & 3 & 12 & 1 \\
\hline & & $\mathrm{E}_{2}$ & & -14.79 to 19.42 & -8.86 to 18.90 & 1 & 11 & 5 & 11 \\
\hline & & $E_{3}$ & & -8.69 to 20.40 & -8.39 to 12.50 & 4 & 1 & 4 & 1 \\
\hline \multirow[t]{3}{*}{14.} & \multirow[t]{3}{*}{ Flag leaf area } & $\mathrm{E}_{1}$ & \multirow[t]{3}{*}{ High } & -30.61 to 16.01 & -28.71 to 10.31 & 2 & 16 & 2 & 18 \\
\hline & & $E_{2}$ & & -20.53 to 27.02 & -17.03 to 36.16 & 2 & 8 & 3 & 8 \\
\hline & & $\mathrm{E}_{3}$ & & -29.05 to 37.24 & -22.94 to 26.27 & 9 & 6 & 9 & 6 \\
\hline \multirow[t]{3}{*}{15.} & \multirow[t]{3}{*}{ Chlorophyll content } & $\mathrm{E}_{1}$ & \multirow[t]{3}{*}{ High } & -42.69 to 25.39 & -23.83 to 43.65 & 11 & 11 & 33 & 4 \\
\hline & & $\mathrm{E}_{2}$ & & -27.35 to 37.38 & -16.09 to 42.45 & 19 & 2 & 25 & 2 \\
\hline & & $E_{3}$ & & -38.80 to 30.24 & -38.15 to 13.53 & 7 & 15 & 8 & 18 \\
\hline
\end{tabular}


Table. 2 Comparative study of six most heterobeltiotic crosses and per se performances for grain yield per plant and its component characters in bread wheat for $\mathrm{E}_{1}$ environment

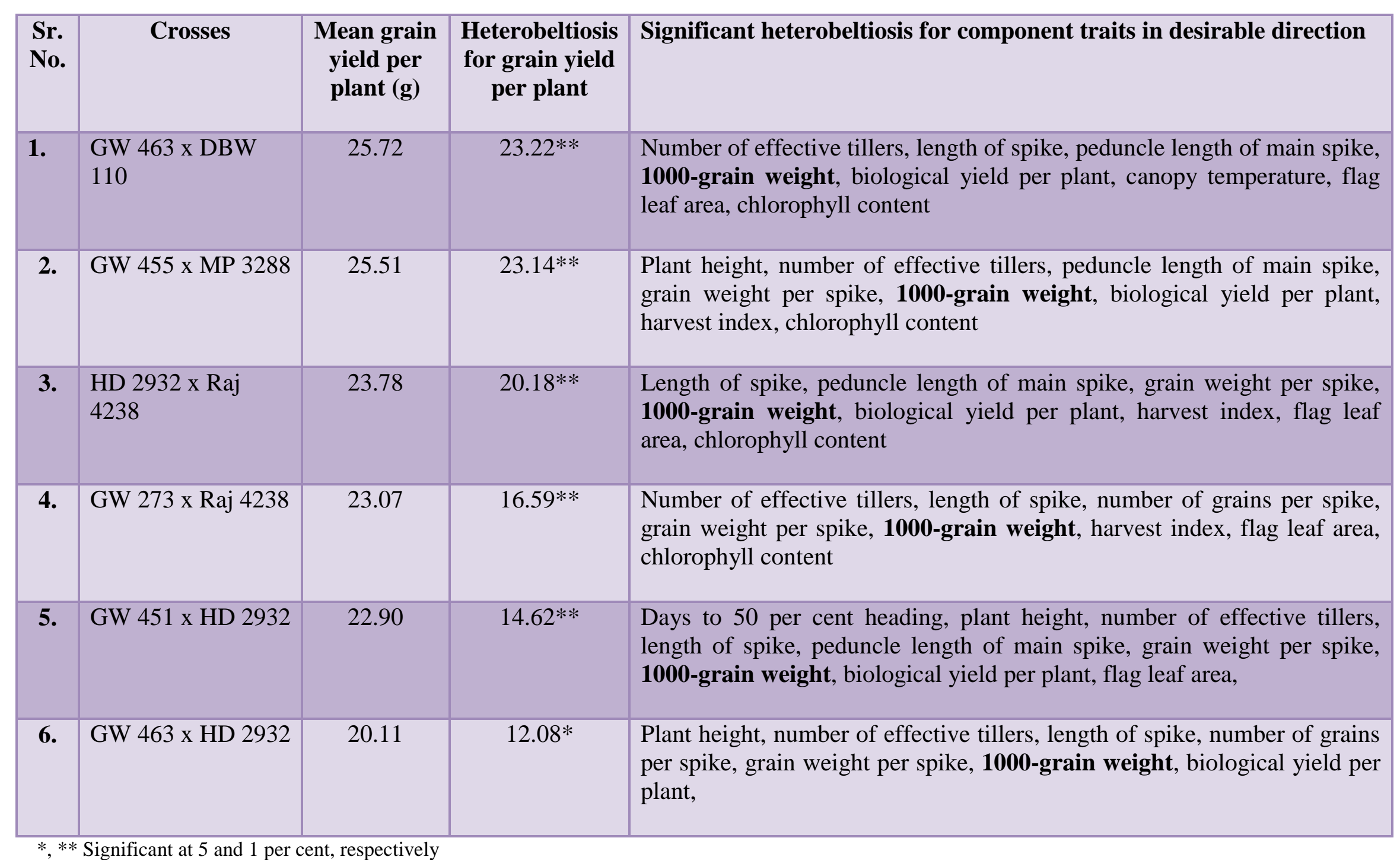


Table.3 Comparative study of six most heterobeltiotic crosses and per se performances for grain yield per plant and its component characters in bread wheat for $\mathrm{E}_{2}$ environment

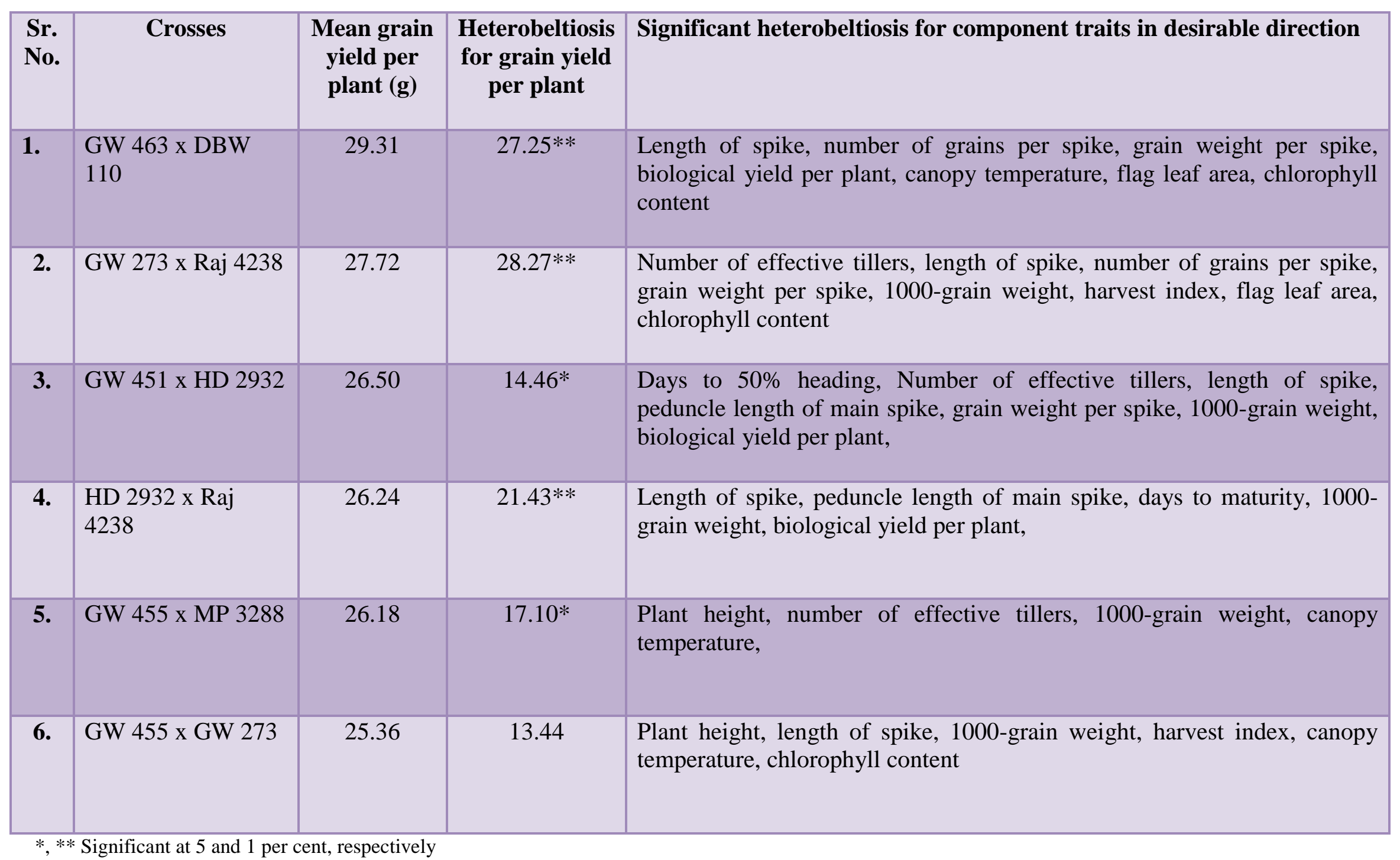


Table.4 Comparative study of six most heterobeltiotic crosses and per se performances for grain yield per plant and its component characters in bread wheat for $\mathrm{E}_{3}$ environment

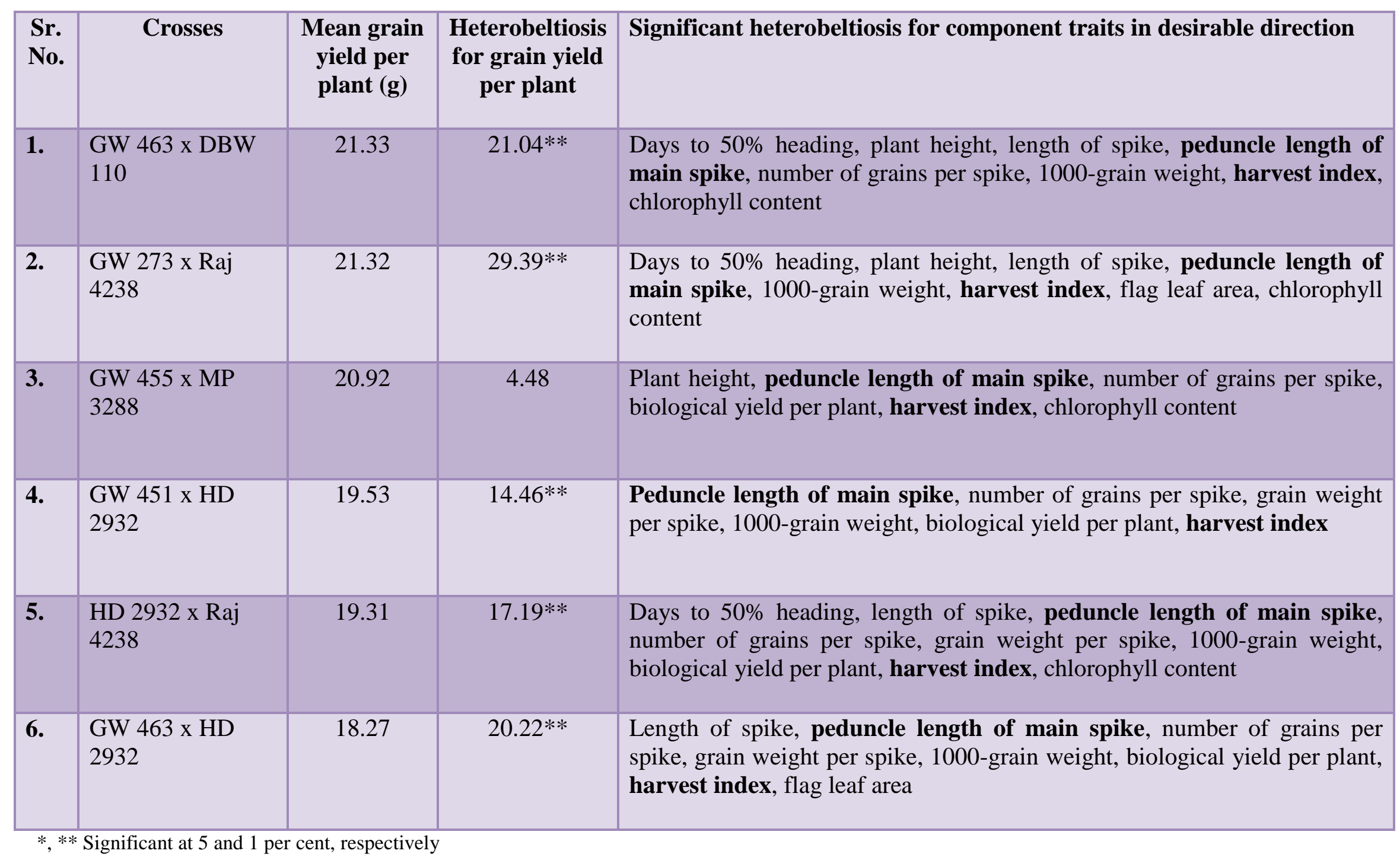


Table.5 Correlation coefficient between per se performance and heterobeltiosis as well as heterobeltiosis and standard heterosisin bread wheat

\begin{tabular}{|c|c|c|c|c|c|c|c|c|c|}
\hline \multirow[t]{2}{*}{$\begin{array}{l}\text { Sr. } \\
\text { No. }\end{array}$} & \multirow[t]{2}{*}{ Characters } & \multicolumn{4}{|c|}{$\begin{array}{c}\text { Per se performance and } \\
\text { heterobeltiosis }\end{array}$} & \multicolumn{4}{|c|}{$\begin{array}{l}\text { Heterobeltiosis and standard } \\
\text { heterosis }\end{array}$} \\
\hline & & $\mathbf{E}_{1}$ & $\mathbf{E}_{2}$ & $\mathbf{E}_{3}$ & pooled & $\mathbf{E}_{1}$ & $\mathbf{E}_{2}$ & $\mathbf{E}_{3}$ & pooled \\
\hline 1. & Day to $50 \%$ heading & $0.95 * *$ & $0.93 * *$ & $0.79 * *$ & $0.91 * *$ & $0.95 * *$ & $0.93 * *$ & $0.79 * *$ & 0.91 ** \\
\hline 2. & Plant height $(\mathrm{cm})$ & $0.91 * *$ & $0.86^{* *}$ & $0.91 * *$ & $0.86 * *$ & $0.91 * *$ & $0.86^{* *}$ & $0.91 * *$ & $0.86^{* * *}$ \\
\hline 3. & No. of effective tillers & $0.89 * *$ & $0.88 * *$ & $0.86 * *$ & $0.83 * *$ & $0.89 * *$ & $0.88 * *$ & $0.86 * *$ & $0.83 * *$ \\
\hline 4. & Length of spike $(\mathrm{cm})$ & $0.85 * *$ & $0.89 * *$ & $0.86^{* *}$ & $0.88 * *$ & $0.85^{* *}$ & $0.89 * *$ & $0.86^{* *}$ & $0.88^{* *}$ \\
\hline 5. & Peduncle length of main spike & $0.66 * *$ & $0.56 * *$ & $0.68 * *$ & $0.50 * *$ & $0.66^{* *}$ & $0.56^{* *}$ & $0.68 * *$ & $0.50^{* *}$ \\
\hline 6. & Days to maturity & $0.76^{* *}$ & $0.70 * *$ & $0.71 * *$ & $0.67 * *$ & $0.76^{* *}$ & $0.70 * *$ & $0.71 * *$ & $0.67 * *$ \\
\hline 7. & Number of grains per spike & $0.64 * *$ & $0.38 * *$ & $0.65 * *$ & $0.51 * *$ & $0.64 * *$ & $0.38^{*}$ & $0.65 * *$ & $0.51 * *$ \\
\hline 8. & Grain weight per spike $(\mathrm{g})$ & $0.72 * *$ & $0.64 * *$ & $0.79 * *$ & $0.69 * *$ & $0.72 * *$ & $0.64 * *$ & $0.79 * *$ & $0.69^{* *}$ \\
\hline 9. & 1000-Grain weight (g) & $0.57 * *$ & $0.52 * *$ & $0.58^{* *}$ & $0.57 * *$ & $0.57^{* *}$ & $0.52 * *$ & $0.58^{* *}$ & $0.57 * *$ \\
\hline 10. & Grain yield per plant $(\mathrm{g})$ & $0.94 * *$ & $0.94 * *$ & $0.62 * *$ & $0.93 * *$ & $0.94 * *$ & $0.94 * *$ & -0.13 & $0.93^{* *}$ \\
\hline 11. & Biological yield per plant $(\mathrm{g})$ & $0.81 * *$ & $0.82 * *$ & $0.32 *$ & $0.80^{* *}$ & $0.81 * *$ & $0.82 * *$ & $0.38 * *$ & $0.80^{\text {** }}$ \\
\hline 12. & Harvest index (g) & $0.94 * *$ & $0.92 * *$ & $0.89 * *$ & $0.92 * *$ & $0.94 * *$ & $0.92 * *$ & $0.70 * *$ & $0.92 * *$ \\
\hline 13. & Canopy temperature $\left({ }^{0} \mathrm{C}\right)$ & $0.84 * *$ & $0.88 * *$ & $0.86^{* *}$ & $0.87 * *$ & $0.84 * *$ & $0.88 * *$ & -0.16 & $0.87 * *$ \\
\hline 14. & Flag leaf area $\left(\mathrm{cm}^{2}\right)$ & $0.91 * *$ & $0.92 * *$ & $0.88^{* *}$ & $0.91 * *$ & $0.91 * *$ & $0.92 * *$ & 0.00 & $0.91 * *$ \\
\hline 15. & Chlorophyll content & $0.82 * *$ & $0.80^{* *}$ & $0.73 * *$ & $0.77 * *$ & $0.82 * *$ & $0.80 * *$ & 0.10 & $0.77 * *$ \\
\hline
\end{tabular}

Highly significant heterobeltiosis in desirable direction was exhibited for number of effective tillers, peduncle length of main spike, 1000-grain weight, grain yield per plant, biological yield per plant and chlorophyll content by cross GW 463 x DBW 110 and GW 455 x MP 3288 in $\mathrm{E}_{1}$ (Table 2); for length of spike, number of grains per spike, grain weight per spike, grain yield per plant, flag leaf area and chlorophyll content by cross GW 463 x DBW 110 and GW 273 x Raj 4238in $\mathrm{E}_{2}$ (Table 3); and for days to $50 \%$ heading, plant height, length of spike, peduncle length of main spike, grain yield per plant, harvest index and chlorophyll content by cross GW 463 x DBW 110 and GW 273 x Raj 4238 in $E_{3}$ (Table 4) which indicated that in different crosses, pathway for releasing heterotic effects varied from cross to cross and also from environment to environment. These results revealed that number of effective tillers, peduncle length of main spike, 1000-grain weight, number of grains per spike, grain weight per spike and chlorophyll content were the main contributor towards increased grain yield.

Thus, heterobeltiosis for various yield contributing characters might be result in the expression of heterobeltiosis for grain yield. However, the crosses showing heterotic expression for grain yield per plant were not heterotic for all the characters. It was also noted that the expression of heterobeltiosis was influenced by the environments for almost all the characters. This was because of significant $\mathrm{G} \times \mathrm{E}$ interaction. The results are in harmony with findings of Thomas et al., (2017).

Several research workers have also reported heterosis in wheat for various component characters like days to 50 per cent heading (Aware and Potdukhe, 2018 and Jaiswal et 
al., 2018),plant height (Thomas et al., 2017), number of effective tillers (Jaiswal et al., 2018), length of spike (Singh et al., 2014; Kumar et al., 2015), peduncle length of main spike (Jaiswal et al., 2018), days to maturity (Lal et al., 2013; Barotet al., 2014), number of grains per spike (Kumar et al., 2011), grain weight per spike (Barot et al., 2014), 1000grain weight (Kumar et al., 2015 and Jaiswal et al., 2018), grain yield per plant (Lal et al., 2013; Gaur et al., 2014), biological yield per plant (Ribadia et al., 2007; Kumar et al., 2014; Kumar et al., 2015 and Jaiswal et al., 2018), harvest index (Desale and Mehta, 2013) and chlorophyll content (Desale and Mehta, 2013).

On the other hand, per se performance of crosses was compared with heterobeltiosis revealed significant and positive correlation between both the parameters for all the characters in $E_{1}, E_{2}, E_{3}$ and pooled (Table 5). Similarly, there was also significant and positive correlation between heterobeltiosis and standard heterosis in all the three individual environments and over environments for all the traits except grain yield per plant, canopy temperature, flag leaf area and chlorophyll content in $E_{3}$ environment.

A comparison of best performing six crosses in order with six most heterotic crosses further revealed that the selection of crosses for grain yield and yield components on the basis of either per se performance or heterotic response would be equally important, but the former is more desirable. Similar findings have been reported by Kumar et al., (2014) and Jaiswal et al., (2018).

\section{References}

Anonymous, 2016. World Agricultural Production, Foreign Agricultural Service, USDA Circular Service,
November 2016.

Anonymous, 2017. Progress Report of All India Co-ordinated Wheat and Barley Improvement Project. Directorate of Wheat Research, Karnal, India.

Aware, S. A. and Potdukhe, N. R. 2018. Heterotic capability of eight crosses for quantitative and qualitative traits in wheat (Triticum aestivum L.) with inbreeding depression studies. International Journal of Current Microbiology and Applied Sciences, 6(S.I.): 2436-2444.

Barot, H. G., Patel, M. S., Sheikh, W. A., Patel, L. P. and Allam, C. R. 2014. Heterosis and combining ability analysis for yield and its component traits in wheat (Triticum aestivum L.). Electronic J. Pl. Br., 5(3): 350-359.

Briggle, L.W. 1963. Heterosis in wheat. A review. Crop Sci. 3: 407-412.

Desale, C. S. and Mehta, D. R. 2013. Heterosis and combining ability analysis for grain yield and quality traits in bread wheat (Triticum aestivum L.). Electronic J. Pl. Br., 4(3): 1205-1213.

Fonseca, S. and Patterson, F.L. 1968. Hybrid vigour in a seven parent diallel cross in common winter wheat (Triticum aestivum L.). Crop Science.8: 85-88.

Gaur, S. C., Singh, S. N., Tiwari, L. P. and Gaur, L. B. 2014. Heterosis and inbreeding depression in the inheritance of grain yield and its components in wheat (Triticum aestivum).Current Advances in Agricultural Sciences, 6(2): 186-189

Grafius, A.E. 1959. Heterosis in barley. Agronomy Journal, 51: 551-554.

Hagberg, A. 1952.Heterosis in F1 combinations in Galeopsis. I and II. Heriditas, Lund. 1:b221- 225. (Fide: Indian J. Genet., 29(1): 53-61).

Hennessy K, Fawcett R, Kirono D, Mpelasoka F, Jones D, Bathols J. 2008. An assessment of the impact of climate 
change on the nature and frequency of exceptional climatic events. CSIRO and Bureau of Meteorology, http://www.daff.gov.au/ data/assets/pdf file/0007/721285/csirobom-reportfuture-droughts.pdf.

Jaiswal, R., Gaur, S. C. and Jaiswal, S. K. 2018.Heterosis and inbreeding depression for grain yield and yield component traits in bread wheat (Triticum aestivum L.). J. Pharmacogn. Phytochem., 7(2): 3586-3594.

Kumar, A., Harshwardhan, A. K. and Prasad, B. 2015.Heterotic performance of diallel $F_{1}$ crosses over parents for yield and its contributing traits in bread wheat. J. Hill Agric., 6(1): 58-61.

Kumar, A., Kumar, V., Kerkhi, S. A., Kumar, S., Chand, P., Kumar, N., Kumar, D. and Kumar, M. 2014. Evaluation of heterosis for yield and yield related traits in bread Wheat (Triticum aestivum L.). Progressive Agriculture, 14(1): 151-159.

Kumar, A., Mishra, V. K., Vyas, R. P. and Singh, V. 2011.Heterosis and combining ability analysis in bread wheat (Triticum aestivum L.). J. Plant Breed. and Crop Sci., 3(10): 209-217.

Lal, C., Kumar, V. and Maloo, S. R. 2013.Heterosis and inbreeding depression for some quantitative and heat tolerance characters in bread wheat (Triticum aestivum L.). J. Wheat Res.,
5(2): 52-55

Reynolds, M., Bonnett, D., Scott, C.C., Robert, T.R., Mane, Y. and Mather, E.D. 2010.Raising yield potential of wheat. I. Overview of a consortium approach and breeding strategies. Journal of Experimental Botany, 62(2):439-452.

Ribadia, K. H., Ponkia, H. P., Dobariya, K. L. and Jivani, L. L. 2007. Combining ability through line $\mathrm{x}$ tester analysis in macaroni wheat (Triticum durum Desf.). J. Maharashtra Agril. Univ., 32: 34-38

Singh, M. K., Sharma, P. K., Tyagi, B. S. and Singh, G. 2014.Heterosis for yield component traits and protein content in bread wheat under normal and heat stress environment. Cereal Res. Commun., 42(1): 151-162.

Thomas, N., Marker, S., Lal, G. M. and Dayal, A. 2017.Study of heterosis for grain yield and its components in wheat (Triticum aestivum) over normal and heat stress conditions. J. Pharmacogn. Phytochem., 6(4): 824-830.

Whitehouse RNH, Thomson JB and Riberio DV. Studies on breeding of selfpollinated cereals II. Use of diallel cross analysis in yield prediction. Euphytica, 1958; 7 : 147-169.

Williams, W. and Gilbert, N. 1960. Heterosis and the inheritance of yield in the tomato. Heredity, 14:133-135.

\section{How to cite this article:}

Ramesh Kumar, D.R. Mehta, V.S. Shekhawat, S. Patel Nikita and Vora Zarna, N. 2019. Heterosis for Grain Yield and Yield Components in Bread Wheat (Triticum aestivum L.) Over Environments. Int.J.Curr.Microbiol.App.Sci. 8(07): 2896-2907. doi: https://doi.org/10.20546/ijcmas.2019.807.360 